http://heanoti.com/index.php/hn

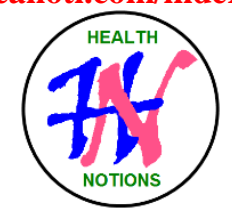

RESEARCH ARTICLE

URL of this article: http://heanoti.com/index.php/hn/article/view/hn30108

\title{
Physical Condition of Dig Well and Incidence of Diarrhea in Infants at The Working Area of Kabila Community Health Center
}

\begin{tabular}{c} 
Bun Yamin M. Badjuka ${ }^{1(\mathrm{CA})}$, Tumartony Thaib Hiola ${ }^{2}$ \\
${ }^{1(\mathrm{CA})}$ Department of Midwifery, Health Polytechnic of Gorontalo, Indonesia; bunyaminbadjuka@gmail.com \\
$\quad$ (Corresponding Author) \\
${ }^{2}$ Department of Midwifery, Health Polytechnic of Gorontalo, Indonesia; tumartony@ gmail.com \\
\hline
\end{tabular}

\begin{abstract}
Dig well is one of the clean water supply sources for the society in the countryside, and urban areas. Dig well provides water originating from the soil layer that is relatively close with ground level, therefore susceptible to contamination through seepage originating from human waste, animals, or for domestic household needs. Dig well as clean water source must be supported by construction conditions, location conditions to build a dig well, this thing is needed so that the quality of dig well's water is safe according to the rules set. The research purpose is to know the physical condition of dig well with incidence of diarrhea in infants at the working area of Kabila Community Health Centre Bone Bolango District. This research used quantitative method, the research instrument uses observation sheet and questionairres to measure the physical condition of dig well. The result show that there was a significant effect between dig well lip height variable, wall of the dig well, septic tank distance with dig well by the incidence of diarrhea in infants. For the variable of dig well floor and closing condition of dig well obtains the result that there was no influence with the incidence of diarrhea in infants.
\end{abstract}

Keywords: Physical condition, Dig well, Diarrhea

\section{Background}

\section{INTRODUCTION}

The quality of clean water used by the society is very influenced by the quality of that water sources besides the water source type used. One of the most used water sources by the society is dig well. Dig well is one of the clean water supply sources for people in rural areas, and urban areas. Dig well provides water that comes from the soil layer that is relatively close to ground level, therefore easily exposed to contamination through seepage that comes from human excrement, animals, and for domestic household needs. Digging wells as a source of clean water must be supported by construction conditions, the location requirements for the construction of a dug well, this is needed so that the quality of the well water is dug safely in accordance with the rules set ${ }^{(1)}$.

The results of the 2013 Riskesdas show that the types of water sources for all household needs in Indonesia in general are protected dug wells (29.2\%), pump wells (24.1\%), and tap water / PDAM (19.7\%). In urban areas, more households use water from bore / pump wells (32.9\%) and tap water / PDAM (28.6\%), while in rural areas more use protected dug wells $(32.7 \%)$. The results of Ramadita's research, Risky et.al (2014) in Blimbingsari Hamlet, the results of the analysis showed that there was a positive relationship between the construction of the dug wells to the bacteriological quality of the dug well water ${ }^{(2)}$. Likewise, the results of the research carried out by Basuki (2004) found a relationship between the physical conditions of the wells digging and the bacteriological quality of well water. One of the diseases caused by bacteriological conditions that do not meet the water requirements is diarrhea, especially in infants The absence of clean water results in diarrheal diseases ${ }^{(3)}$.

The number of diarrhea cases in Gorontalo Province amounted to 16,206 cases and for Bone Bolango Regency amounted to 2,128 cases with the most cases in Kabila Public Health Center as many as 309 cases. Kabila Community Health Center is one of the technical implementation units of the Bone Bolango District Health Office that uses the most dug wells as a source of clean water, which is 2,442 dug wells consisting of 1,831 protected dug wells and 611 uncovered wells. Dug wells that do not have good construction can be a risk factor for the transmission of diarrheal diseases. The results of a preliminary study of 10 respondents in the Kabila Community Health Center work area, $100 \%$ used ground water for drinking and cooking. 


\section{METHODS}

This research was analytic survey research with cross sectional study approach. This research was conducted in the working Area of Kabila Community Health Centre Bone in Bolango District. The population was the whole research object or the object under study. The sample in this research was which meets the sample criteria, that was: 1). Inclusive Criteria; Citizens who have dig well and have a toddler and have suffered from diarrhea in the last 3 months, 2). Exclusive Criteria; Citizens who have dig well and have toddler and have never suffered diarrhea in the last 3 months. The data collected in this research were primary data and secondary data. The time of the research was begun on September 6th untill October 31st, 2018 at the Working Area of Kabila Community Health Centre Bone Bolango District.

Data analysis technique was univariate analysis, bivariate analysis to determine whether there was influence between independent variables on the dependent variable was chi-square statistical analysis with the SPSS For Windows program, and mltivariate analysis to find out which independent variable show the most dominant effect on the variable. The step in multivariate analysis were as follows selection of candidates model, making a determining factor model, and interaction test.

\section{RESULTS}

\section{Description of Dig Well Condition}

Table 1. High dig well lips condition

\begin{tabular}{c|c|c}
\hline High Lips Condition & Total & Percentage \\
\hline Qualified & 12 & 40 \\
\hline Unqualified & 18 & 60 \\
\hline Total & 30 & 100 \\
\hline
\end{tabular}

The results of the research of high dig well lips condition shows that from 30 dig wells found 18 dig wells unqualified $(60 \%)$

Table 2. Dig well floor condition

\begin{tabular}{c|c|c}
\hline Dig Well Floor Condition & Total & Percentage \\
\hline Qualified & 12 & 40 \\
\hline Unqualified & 18 & 60 \\
\hline Total & 30 & 100 \\
\hline
\end{tabular}

The results of the research dig well floor condition shows that from 30 dig wells found 18 dig wells did unqualified $(60 \%)$.

Table 3. Dig well wall condition

\begin{tabular}{c|c|c}
\hline Dig Well Floor Condition & Total & Percentage \\
\hline Qualified & 9 & 30 \\
\hline Unqualified & 21 & 70 \\
\hline Total & 30 & 100 \\
\hline
\end{tabular}

The results of the research of dig well wall condition shows that from 30 dig wells found 21 dig wells did unqualified $(70 \%)$.

Table 4. The distance of septic tank with dig well

\begin{tabular}{c|c|c}
\hline Distance of Septic Tank with Dig Well & Total & Percentage \\
\hline Qualified & 4 & 13.3 \\
\hline Unqualified & 26 & 86.7 \\
\hline Total & 30 & 100 \\
\hline
\end{tabular}

The results of the research of the distance of septic tank with respondent's dig well shows that from 30 dig wells found 26 dig wells did unqualified $(86.7 \%)$. 
Table 5. Dig well cover condition

\begin{tabular}{c|c|c}
\hline Dig Well's Cover Condition & Total & Percentage \\
\hline Qualified & 6 & 20 \\
\hline Unqualified & 24 & 80 \\
\hline Total & 30 & 100 \\
\hline
\end{tabular}

The results of the research of dig well's cover condition shows that from 30 dig wells found 24 dig wells did unqualified $(80 \%)$.

Table 6. Dig well water bacteriology quality

\begin{tabular}{c|c|c}
\hline Total Coliform in 100 ml Dig Well Water Sample & Total & Percentage \\
\hline Qualified & 9 & 30 \\
\hline Unqualified & 21 & 70 \\
\hline Total & 30 & 100 \\
\hline
\end{tabular}

The results of the research of dig well water bacteriology quality test shows that from 30 dig wells found 21 dig wells did unqualified (70\%).

\section{Bivariate Analysis}

Table 7. The influence of high dig well lips condition to the toddlers diarrhea incidence

\begin{tabular}{|c|c|c|c|c|c|c|c|c|c|}
\hline \multirow{3}{*}{$\begin{array}{l}\text { High dig well lips } \\
\text { condition }\end{array}$} & \multicolumn{4}{|c|}{ Incidence of diarrhea } & \multirow{2}{*}{\multicolumn{2}{|c|}{ Total }} & \multirow{3}{*}{$\begin{array}{c}\mathrm{X}^{2} \\
\mathrm{p} \text {-value }\end{array}$} & \multirow{2}{*}{ OR } & \multirow{2}{*}{$\mathrm{CI}$} \\
\hline & \multicolumn{2}{|c|}{ Diarrhea } & \multicolumn{2}{|c|}{ No diarrhea } & & & & & \\
\hline & $\mathrm{f}$ & $\%$ & $f$ & $\%$ & $\mathrm{n}$ & $\%$ & & \multirow{4}{*}{0.167} & \multirow{4}{*}{$0.33-0.853$} \\
\hline Qualified & 3 & 25 & 9 & 75 & 12 & 100 & \multirow{3}{*}{$\begin{array}{l}5.000 \\
0.025\end{array}$} & & \\
\hline Unqualified & 12 & 66.7 & 6 & 33.7 & 18 & 100 & & & \\
\hline Total & 15 & 50 & 15 & 10 & 30 & 100 & & & \\
\hline
\end{tabular}

The results of the research shows that the most toddlers who suffer from diarrhea using water from dug wells with unqualified high wells lip as 12 respondents $(66.7 \%)$. The result of statistic test shows that $\mathrm{p}$-value = 0.025 ( $\mathrm{p}<0.05)$, namely there was a influence between high dig well lips condition to the toddlers diarrhea incidence.

Table 8. The influence of dig well floor condition to the toddlers diarrhea incidence

\begin{tabular}{|c|c|c|c|c|c|c|c|c|c|}
\hline \multirow{3}{*}{ Dig Well Floor Condition } & \multicolumn{4}{|c|}{ Incidence of diarrhea } & \multirow{2}{*}{\multicolumn{2}{|c|}{ Total }} & \multirow{3}{*}{$\begin{array}{c}\mathrm{X}^{2} \\
\mathrm{p} \text {-value }\end{array}$} & \multirow{3}{*}{ OR } & \multirow{2}{*}{$\mathrm{CI}$} \\
\hline & \multicolumn{2}{|c|}{ Diarrhea } & \multicolumn{2}{|c|}{ No diarrhea } & & & & & \\
\hline & $\mathrm{f}$ & $\%$ & $\mathrm{f}$ & $\%$ & $\mathrm{n}$ & $\%$ & & & \multirow{4}{*}{$0.130-2.503$} \\
\hline Qualified & 5 & 41.7 & 7 & 58.3 & 12 & 100 & \multirow{3}{*}{$\begin{array}{l}0.556 \\
0.456\end{array}$} & \multirow{3}{*}{0.571} & \\
\hline Unqualified & 10 & 55.6 & 8 & 44.6 & 18 & 100 & & & \\
\hline Total & 15 & 50 & 15 & 10 & 30 & 100 & & & \\
\hline
\end{tabular}

The results of the research shows that the most toddlers who suffer from diarrhea using water from dug wells with unqualified floor condition as 10 respondents $(55.6 \%)$. The result of statistic test shows that $\mathrm{p}$-value $=$ 0.456 ( $p>0.05$ ), namely there was not an influence between dig well floor condition to the toddlers diarrhea incidence.

Table 9. The Influence of Dig Well Wall Condition to the Toddlers Diarrhea Incidence

\begin{tabular}{|c|c|c|c|c|c|c|c|c|c|}
\hline \multirow{3}{*}{ Dig Well Wall Condition } & \multicolumn{4}{|c|}{ Incidence of diarrhea } & \multirow{2}{*}{\multicolumn{2}{|c|}{ Total }} & \multirow{3}{*}{$\begin{array}{c}X^{2} \\
\text { p-value }\end{array}$} & \multirow{3}{*}{ OR } & \multirow{2}{*}{$\mathrm{CI}$} \\
\hline & \multicolumn{2}{|c|}{ Diarrhea } & \multicolumn{2}{|c|}{ No diarrhea } & & & & & \\
\hline & $\mathrm{f}$ & $\%$ & $\mathrm{f}$ & $\%$ & $\mathrm{n}$ & $\%$ & & & \multirow{4}{*}{$1.780-6.683$} \\
\hline Qualified & 0 & 0 & 9 & 100 & 9 & 100 & \multirow{3}{*}{$\begin{array}{c}12.857 \\
0.000\end{array}$} & \multirow{3}{*}{3.500} & \\
\hline Unqualified & 15 & 71.4 & 6 & 28.6 & 21 & 100 & & & \\
\hline Total & 15 & 50 & 15 & 50 & 30 & 100 & & & \\
\hline
\end{tabular}


The results of the research shows that the most toddlers who suffer from diarrhea using water from dug wells with unqualified wall condition as 15 respondents $(71.4 \%)$. The result of statistic test shows that $\mathrm{p}$-value $=$ 0.000 ( $>>0.05)$, namely there was an influence between dig well wall condition to the toddlers diarrhea incidence.

Table 10. The influence of septic tank distance with dig well to the toddlers diarrhea incidence

\begin{tabular}{|c|c|c|c|c|c|c|c|c|c|}
\hline \multirow{3}{*}{$\begin{array}{c}\text { The Distance of Septic Tank } \\
\text { with Dig Well }\end{array}$} & \multicolumn{4}{|c|}{ Incidence of diarrhea } & \multirow{2}{*}{\multicolumn{2}{|c|}{ Total }} & \multirow{2}{*}{$\begin{array}{c}\mathrm{X}^{2} \\
\mathrm{p} \text {-value }\end{array}$} & \multirow{2}{*}{ OR } & \multirow{2}{*}{ CI } \\
\hline & \multicolumn{2}{|c|}{ Diarrhea } & \multicolumn{2}{|c|}{ No diarrhea } & & & & & \\
\hline & $\mathrm{f}$ & $\%$ & $\mathrm{f}$ & $\%$ & $\mathrm{n}$ & $\%$ & \multirow{4}{*}{$\begin{array}{l}4.658 \\
0.031\end{array}$} & \multirow{4}{*}{0.107} & \multirow{4}{*}{$0.14-1.044$} \\
\hline Qualified & 1 & 14.3 & 6 & 85.7 & 7 & 100 & & & \\
\hline Unqualified & 14 & 60.9 & 9 & 39.1 & 23 & 100 & & & \\
\hline Total & 15 & 50 & 15 & 50 & 30 & 100 & & & \\
\hline
\end{tabular}

The results of the research shows that the most toddlers who suffer from diarrhea using water from dug wells with unqualified septic tank distance with dig well as 14 respondents $(60.9 \%)$. The result of statistic test shows that $\mathrm{p}$-value $=0.031(\mathrm{p}<0.05)$, namely there was an influence between septic tank distance with dig well to the toddlers diarrhea incidence.

Table 11. The influence of dig well's cover to the toddlers diarrhea incidence

\begin{tabular}{|c|c|c|c|c|c|c|c|c|c|}
\hline \multirow{3}{*}{ Dig Well's Cover Condition } & \multicolumn{4}{|c|}{ Incidence of diarrhea } & \multirow{2}{*}{\multicolumn{2}{|c|}{ Total }} & \multirow{3}{*}{$\begin{array}{c}X^{2} \\
\text { p-value }\end{array}$} & \multirow{2}{*}{ OR } & \multirow{2}{*}{$\mathrm{CI}$} \\
\hline & \multicolumn{2}{|c|}{ Diarrhea } & \multicolumn{2}{|c|}{ No diarrhea } & & & & & \\
\hline & $\mathrm{f}$ & $\%$ & $\mathrm{f}$ & $\%$ & $\mathrm{n}$ & $\%$ & & \multirow{4}{*}{0.423} & \multirow{4}{*}{$0.065-2.766$} \\
\hline Qualified & 2 & 33.3 & 4 & 66.7 & 6 & 100 & \multirow{3}{*}{$\begin{array}{l}0.833 \\
0.361\end{array}$} & & \\
\hline Unqualified & 13 & 54.2 & 11 & 45.8 & 24 & 100 & & & \\
\hline Total & 15 & 50 & 15 & 50 & 30 & 100 & & & \\
\hline
\end{tabular}

The results of the research shows that the most toddlers who suffer from diarrhea using water from dug wells with unqualified dig well's cover as 13 respondents $(54.2 \%)$. The result of statistic test shows that p-value $=0.361(\mathrm{p}>0.05)$, namely there was not an influence between dig well's cover to the toddlers diarrhea incidence.

\section{Multivariate Analysis}

Table 12. The selection result of model candidates between independent variables and dependent variables

\begin{tabular}{clc}
\hline No & Variable & p-value \\
\hline 1 & Digging Well Lips Height & 0.032 \\
2 & Dig Well Floor & 0.458 \\
3 & Dig Well Wall & 0.999 \\
4 & Distance of Septic Tank with Dig Well & 0.054 \\
5 & Dig Well Cover & 0.369 \\
\hline
\end{tabular}

Analysis result shows p value digging well lips height (0.032) and distance of septic tank with dig well (0.054) entered to multivariate test because the $\mathrm{p}$-value $<0.25$.

Table 13. Multivariate analysis result between digging well lips height and the distance of septic tank with dig well with the incidence of diarrhea

\begin{tabular}{lcccccccc}
\hline No & \multirow{2}{*}{ Variable } & \multirow{2}{*}{ S.E } & Wald & df & \multirow{2}{*}{ Sig. } & \multirow{2}{*}{ Exp (B) } & \multicolumn{2}{c}{ 95\% C.I for EXP (B) } \\
\hline 1 Digging Well Lips Height & 1.792 & 0.833 & 4.623 & 1 & 0.032 & 6.000 & 1.172 & Upper \\
2 Dig Well Floor & 0.560 & 0.754 & 0.551 & 1 & 0.458 & 1.750 & 0.400 & 7.664 \\
3 Dig Well Wall & 22.119 & 133397.657 & 0.000 & 1 & 0.999 & 4038687160.944 & 0.000 & - \\
4 Distance of Septic Tank & 2.234 & 1.162 & 3.698 & 1 & 0.054 & 9.333 & 0.058 & 90.940 \\
$\quad$ with Dig Well & & & & & & & & \\
5 Dig Well Cover & 0.860 & 0.958 & 0.806 & 1 & 0.369 & 2.364 & 0.361 & 15.455 \\
\hline
\end{tabular}

Modelling Variable Determinants Factors using multiple logistic regression analysis. Analysis results shows there are 2 variable that have probability value (p-value) $<0.05$ which is dig well lips $(0.032)$ and the 
distance of septic tank with dig well (0.054). this results shows that the variables have a signifikan relation with the toddlers diarrhea incidence.

Table 14. Interaction test result between digging well lips and the distance of septic tank with dig well with the toddlers diarrhea incidence

\begin{tabular}{llc}
\hline No & \multicolumn{1}{c}{ Interactive } & p-value \\
\hline 1 & Height of digging well lips * Incidence of diarrhea to toddlers & 0.032 \\
\hline 2 & Distance of septic tank with dig well * Incidence of diarrhea to toddlers & 0.054 \\
\hline
\end{tabular}

Analysis result shows that the coefficient p-value (2.234) of the distance of septic tank with dig well is higher than the dig well lip valiable. thats mean the distance of septic tank with dig well is the most influence dominan variable to the toddlers diarrhea incidence.

\section{DISCUSSION}

Data from the research results in Table 7 show that $25 \%$ of children under five who suffer from diarrhea who use well water with digging wells that meet the requirements are still found, whereas for toddlers who use water with lip height dug wells that do not meet health requirements are $66.7 \%$. From the results of statistical tests obtained $\mathrm{X}^{2}$ count (5.000)> $\mathrm{X}^{2}$ table (3.841) and $\mathrm{p}$ value $=0.025<0.05$ with a degree of significance $\alpha=0.05$, then Ho is rejected. Statistically, it can be interpreted that there is a significant influence on the well lip digging with the incidence of toddler diarrhea in the working area of Kabila Health Center, Bone Bolango District.

In accordance with the theory of parapet lips is a wall that limits the mouth of the well and must be made as high as $70-75 \mathrm{~cm}$ from the ground. This wall is a unit with a well wall. If the area is a flood area, the height of the wall of the well above the ground is approximately $70 \mathrm{~cm}$, or higher than the surface of the flood water ${ }^{(4)}$. This research is in line with research by Ira, et al. (2013) that the walls of the dug wells have met the health requirements of $80 \mathrm{~cm}$ height. Parapet wall function in addition to the safety of the use of wells, also functions to prevent the entry of pollutants into the well ${ }^{(5)}$.

Based on table 8 shows that toddlers who suffer from diarrhea with the condition of the dug well floor that meet the requirements $41.7 \%$ lower than toddlers who do not suffer from diarrhea. The opposite is true for toddlers who experience diarrhea with the condition of the dug well floor that does not meet more health requirements (55.6\%) compared to those without diarrhea. From the results of the statistical test obtained $\mathrm{X}^{2}$ count $(0.556)<\mathrm{X}^{2}$ table (3.841) and $p$ value $=0.456<0.05$ with a degree of significance $\alpha=0.05$, then Ho is accepted. Statistically, it can be interpreted that there is no influence on the well floor digging with the incidence of diarrhea in toddlers in the work area of Kabila Health Center, Bone Bolango District. The results of this study are in line with the research conducted by Khomariyatika and Pawenang (2011) entitled Water Bacteriological Quality of Gali Wells, stating that there is no relationship between the well floor and the bacteriological quality of the dug wells ${ }^{(6)}$.

The absence of influence on the condition of the digging floor on the incidence of diarrhea is likely caused by other factors that are more influential, for example, the incidence of diarrhea experienced by toddlers can also be caused by food or other physical conditions. However, it should be noted that based on the results of observations and measurements it was found that $60 \%$ of the dug wells were categorized as not meeting the requirements in terms of the physical condition of the waterproof floor with a diameter of less than 1 meter.

In accordance with the existing theory by Budiman (2007) that the well floor is made of waterproof walls (cement) with a diameter of $\pm 1 \mathrm{~m}$ from the wall or the lip height of the well dug with a slope of about 5-10 degrees towards the drainage. In addition, the ground around the top of the well wall must be cemented and the ground made tilted with a channel. The width of the cement around the well is approximately 1.5 meters so that surface water does not enter ${ }^{(7)}$. Based on table 9 shows that toddlers who use clean water from dug wells that have walls meet all requirements (100\%) do not suffer from diarrhea, while toddlers who use clean water from wells dug with the well walls do not meet most requirements $(71.4 \%)$ experiencing diarrhea. The results of statistical tests obtained $\mathrm{X}^{2}$ count (12.857) $>\mathrm{X}^{2}$ tables (3.841) and $\mathrm{p}$ value $=0.000<0.05$ with a degree of significance $\alpha=0.05$, then Ho is rejected. Statistically, it can be interpreted that there is a very significant effect on the well wall digging with the incidence of diarrhea in toddlers in the work area of Kabila Health Center, Bone Bolango District.

Observation data shows that as many as $70 \%$ of dug wells do not meet the requirements because they have a wall of watertight wells of less than 3 meters, some are not even plastered, only a stack of bricks is stacked and the average is water resistant as deep as $20-50 \mathrm{~cm}$. In addition, the condition of the well wall is not cleaned so that it is overgrown with moss. According Prajawati (2008) This causes the coliform bacteria content of dug well water to not meet the requirements because the ability of pathogenic bacteria to penetrate the soil vertically is 3 meters deep. If the physical condition of the wall of the well dug is not water resistant as deep as $\geq 3$ meters, it will be easily contaminated by pathogenic bacteria, especially coliform bacteria because of the ability to penetrate the soil vertically as deep as 3 meters. 
Based on Table 10 shows that there is still one toddler $(14.3 \%)$ who uses clean water from dug wells that meet the requirements, while toddlers who use dug well water that do not meet the requirements most $(60.9 \%)$ experience diarrhea. The results of the statistical test obtained $X$ count (4.658)> $X^{2}$ table $(3.841)$ and $p$ value $=$ $0.031<0.05$ with the degree of significance $\alpha=0.05$, then Ho is rejected. Statistically, it can be interpreted that there is a significant influence on the distance between septic tanks and dug wells to the incidence of diarrhea in toddlers in the work area of Kabila Health Center, Bone Bolango District. The results of the same study were also obtained by Sapulete (2010) wherein the study found that there was a very significant relationship between dug wells and septic tanks with fecal coliform (E. coli) content as the bacteria causing diarrhea in well water dig it out (8).

This research is also supported by research conducted by Ameliah (2017) on the relation of wells digested factors to the Fecal Coliform index in Sentul Village, Kragilan Subdistrict, Serang District, where results were found to correlate septic tank distance with Fecal coliform index well dug water ${ }^{(9)}$. 30 observatory wells $86.7 \%$ were categorized as not fulfilling the requirements because they had a distance of less than 10 with a pollutant source (septic tank). This is due to the fact that many houses that have land and courtyards that are turned into simple cattle pens because the livestock business in Kabila Subdistrict is promising for additional income for the local residents. While for sewerage (SPAL) livestock cages are directly channeled to the surface of the land with the location of farms higher than the dig well facilities. This is the cause of the problem of bacteriological content of coliform wells dug exceeding the required standards.

Theoretically from a sanitation point of view, what is important to note is the maximum displacement distance from pollutants and the fact that the direction of displacement is always in the direction of groundwater flow. Water pollution can occur due to the disposal of household sewage to the surrounding soil. Then the water will seep into the ground. Pollution caused by bacteria on water in the soil can reach a distance of 11 meters in the direction of groundwater flow, if the distance of the septic tank is less than 11 meters it can cause contamination of groundwater such as dug well water ${ }^{(9)}$. Water from dug wells less than 11 meters from the septic tank is estimated to contain coliform bacteria, especially fecal coliform bacteria ${ }^{(10)}$. Distance is one of the factors that can influence the pattern of the spread of growth and breeding of microorganisms. This theory was supported by Budiman (2007) that The distance of wells is at least 15 meters and higher than sources of pollution such as latrines, livestock pens, trash bins, etc.

Based on the results of the analysis, multivariate B coefficients were obtained, where the Septic Tank Distance with Gali Well is the variable that has the highest coefficient B (2.234) when compared with other variables. These results indicate that the distance of Septic Tank with Gali Well is the most dominant variable influencing the incidence of Diarrhea in Toddlers in the working area of Kabila Health Center, Bone Bolango Regency. This research is in line with research by Ira, et,al. (2013) entitled "Overview of Physical and Bacterological Quality of Water and Physical Condition of Dug Wells in Bitung Karangria Sub-District, Tuminting District, Manado City" discussing the location of dug wells for pollutant sources such as septic tanks, livestock pens , puddles, waste collection sites that must be $\geq 11$ meters from the dug wells.

Based on table 11, it is found that toddlers who use clean water from wells that have cover are still found $33.3 \%$ experience diarrhea while toddlers who use clean water from wells that do not have cover (54.2\%) experience diarrhea. From the results of statistical tests obtained $X^{2}$ count $(0.883)<X^{2}$ table (3.841) and $p$ value $=0.361<0.05$ with a degree of significance $\alpha=0.05$, then Ho is accepted. Statistically it can be interpreted that there is no effect of the dug well cover on the incidence of diarrhea in toddlers in the working area of Kabila Health Center, Bone Bolango District. The absence of the influence of the dug well cover on the incidence of diarrhea may be caused due to other factors that are more influential such as the incidence of diarrhea experienced by toddlers can also be caused by food factors and other physical conditions such as the direction of water flow, slope of the land, and others.

The results of observations and measurements in the field, as many as $80 \%$ of dug wells are categorized as not fulfilling the requirements in terms of the physical condition of the watertight cover. In reality, there are still many dug wells found that do not use waterproof caps, but the reason the dug wells do not use a waterproof cap because most of the dug wells are located outside the house and close to cattle pens, therefore do not use the lid because it feels safe from contamination and when using the lid it is considered inefficient because of the high intensity of water extraction so that residents are reluctant to open the cover. Based on the results of these field observations, the condition of the dug well cover that does not meet this requirement is very appropriate to note that the well water is not contaminated with bacteria from outside the well. In accordance with Budiman (2007) the well should be closed with a cover made of stone, especially in public wells. Such caps can prevent contamination directly in the well.

\section{CONCLUSION}

The research result shows that there is a significant influence between the height of the lip well dig, the dig well wall, the distance of the septic tank with the well dug with the incidence of diarrhea in infants. For the 
variables of the dig well floor and the condition of the dug well cover, the results showed that there was no effect on the incidence of diarrhea in infants. It is advised to do improvement effort to dug well facilities and prevention of clean water pollution by regularly educating the community in order to fulfill the quality of dug well water.

\section{REFERENCES}

1. Notoatmodjo S. Public Health, Basic Principles (Ilmu Kesehatan Masyarakat, Prinsip-Prinsip Dasar). Jakarta: Rineka Cipta; 2003.

2. Ramadita Ret al. Study of Bacteriological Quality of Well Digging in Settlement Areas Using B16 TECTATM Biosensor (Studi Kualitas Bakteriologis Air Sumur Gali pada Kawasan Permukiman Menggunakan Biosensor TECTATM B16 (Studi Kasus: Dusun Blimbingsari dan Dusun Wonorejo, Kabupaten Sleman Jurusan Teknik Lingkungan, Fakultas Teknik Sipil dan Perencanaan, Universitas Islam Indonesia). JA-FTSP, Universitas Islam Indonesia; 2014.

3. Basuki. The Relationship Between Physical Conditions of Wells and Their Quality of Water Bacteriology in Karangtengah Village, Banjarnegara Regency (Hubungan Antara Kondisi Fisik Sumur Gali Dengan Kualitas Bakteriologis Air Di Desa Karang tengah Kabupaten Banjarnegara). Semarang: FKM; Universitas Diponegoro; 2004.

4. Budiman C. Introduction of Environmental Health (Pengantar kesehatan Lingkungan). Jakarta: EGC; 2007.

5. Ira A. Overview of Physical and Bacteriological Quality of Water and Physical Condition of Well Digging in Bitung Karangria Sub-District, Tuminting District, Manado City (Gambaran Kualitas Fisik dan Bakteriologis Air Serta Kondisi Fisik Sumur Gali di Kelurahan Bitung Karangria Kecamatan Tuminting Kota Manado). Jurnal Kesmas Universitas Sam Ratulangi. 2013.

6. Khomariyatika T, Pawenang ET. Bacteriological Quality of Water Well Digest (Kualitas Bakteriologis Air Sumur Gali). Jurnal Kesehatan Masyarakat. 2011;7(1).

7. Prajawati R. Relationship of Construction with the Quality of Water Microbiology of Dug Wells (Hubungan Konstruksi dengan Kualitas Mikrobiologi Air Sumur Gali). Kesehatan Lingkungan. 2008;2(1).

8. Sapulete MR. Relationship between Septic Tank Distance to Digging Wells and Escherichia Coli Content in Gali Well Water Tuminting District, Manado City (Hubungan antara Jarak Septic Tank ke Sumur Gali dan Kandungan Escherichia Coli dalam Air Sumur Gali Kecamatan Tuminting Kota Manado). Biomedik. 2010;2(3).

9. Amaliah L. Analysis of the Relationship of Well Sanitary Digging Factors to the Fecal Coliform Index in Sentul Village, Kragilan District, Serang Regency (Analisis Hubungan Faktor Sanitasi Sumur Gali Terhadap Indeks Fecal Coliform di Desa Sentul Kecamatan Kragilan Kabupaten Serang). Undergraduate Thesis. Jakarta: FKIK; 2017.

10. Ridhosari B, Roosmini D. Evaluation of Tanha Water Quality from Wells Digging Due to Domestic Activities in Darulin-Desa Nanjung Village (Evaluasi Kualitas Air Tanha dari Sumur Gali Akibat Kegiatan Domestik di Kampung Darulin-Desa Nanjung). Teknik Lingkungan. 2011;17(1). 